\title{
Evaluation of fertilization of hydroponically cultivated castor bean (Ricinus communis L.)
}

\author{
Gómez-González, Adrían ${ }^{1}$; Reyes-Contreras, J.G. ${ }^{2}$; García-Herrera, E. Javier ${ }^{1^{*}}$; Hernández-Ríos, \\ Ismael $^{1}$; Amante-Orozco, Alejandro ${ }^{1}$; Méndez-Gallegos, S. de Jesús ${ }^{1}$; Silos-Espino, H. $^{3}$.
}

\begin{abstract}
${ }^{1}$ Posgrado de Innovación en Manejo de Recursos Naturales, Colegio de Postgraduados, Campus San Luis Potosí, Salinas de Hidalgo, San Luis Potosí, México. ²Egresado de Maestría Tecnológica en Producción Sustentable de Bioenergéticos, Colegio de Postgraduados, Campus San Luis Potosí, Salinas de Hidalgo, San Luis Potosí, México. ${ }^{3}$ Intituto Tecnológico El Llano, Aguascalientes, México.
\end{abstract}

*Corresponding author: garciae(acolpos. $\mathrm{mx}$

\begin{abstract}
Objective: To determine the influence of fertilization on the growth and yield of five accessions of castor bean (Ricinus communis L.) cultivated in a hydroponic system.

Design/Methodology/Approach: Five outstanding accessions of the castor bean collection at COLPOS-Campus SLP were established: El Orito (EO), Encarnación de Díaz (ED), Salinas (SA), Ranchería de Guadalupe (RG) and San Luis (SL). The NPK (ppm) fertilization levels tested were: Iow (LL; 140, 50, 150), medium (ML; 210, 80, 250); high (HL; 280, 110, 350) and a control (NF; No fertilizer). The experimental design was a randomized block, with a $5 \times 4$ factorial arrangement (accession $\times$ fertilizer level)

Results: The differences in grain production were only significant $(\alpha=0.05)$ between the NF control (31 g plant $\left.{ }^{-1}\right)$ and the three levels of fertilization (1103, 973 and $967 \mathrm{~g} \mathrm{plant}^{-1}$, for LL, ML, and HL, respectively, with no differences among them). Regarding accessions, no differences were observed among them, having ED the highest yield (681 $\mathrm{g}$ plant ${ }^{-1}$ ). In the case of plant height, NF treatment reached $60 \mathrm{~cm}$, while the other levels had an average height of $170 \mathrm{~cm}$, with $\mathrm{HL}$ being the highest $(180 \mathrm{~cm})$. The highest oil content $(38.4 \%)$ was obtained with the ML fertilization.
\end{abstract}

Study Limitations/Implications: The present study had no obvious limitations.

Findings/Conclusions: For seed yield, significant differences were found only between not fertilizing and fertilizing at any level. Between fertilized levels, however, the differences were not significant, as well as among accessions.

Keywords: yield, oil content, production systems, plant nutrition.

\section{INTRODUCTION \\ In Mexico}

there are plant species with bioenergetic potential, among which the following stand out: Mexican pine nut (Jatropha curcas L.), castor bean (Ricinus communis L.), sweet sorghum (Sorghum bicolor (L.) Moench) (SAGARPA, 2017), and prickly pear cactus (Opuntia spp) (Amante et al., 2013), among others.

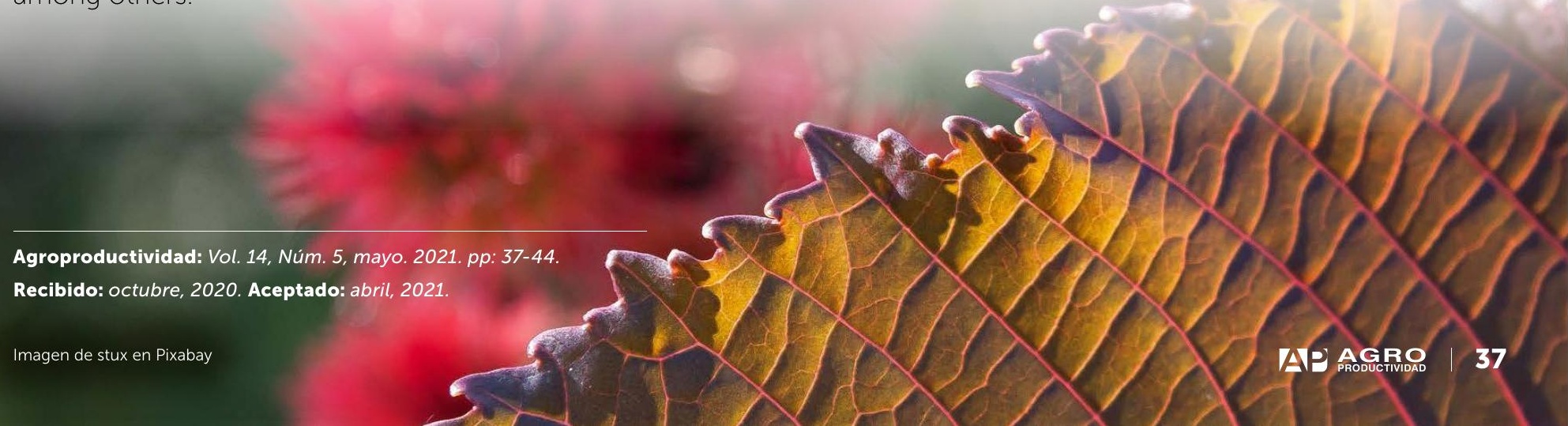


Castor bean ( $R$. communis) is a species of tropical origin, with a wide adaptation and distribution in the world. It is an important nonedible commercial oilseed crop that tolerates drought and has a good productive behavior in arid and semi-arid regions (Babita et al., 2010). Currently, it is used in the chemical industry known as ricinochemistry; the oil produced in its seed is the only one in nature that is soluble in alcohol, and also has a high density and viscosity. Castor bean seeds are a source of ricinoleic acid, which confers interesting industrial properties for the production of various products, including: inks, medicines, varnishes, synthetic polymers, hydraulic fluids, fuel additives, plastics, lubricants, cosmetics, low molecular weight aviation fuels, and biodiesel (Caupin, 1997; Beltrão et al., 2001; Comar et al., 2004; Velasco et al., 2005; Ogunniyi, 2006; Cardona et al., 2009). After detoxification, the seed residues can be used to produce animal feed supplements or as organic fertilizer (Jiménez et al., 2016)

According to Severino et al. (2006), castor bean is a demanding crop in terms of soil fertility, when high productivity is sought. In turn, Magalhães et al. (2002) mentioned that low potassium levels affect growth and vegetative reproduction, while the lack of micronutrients is mainly expressed in production. In general, there is limited information on castor bean responses to chemical fertilization with nitrogen, phosphorus and potassium (NPK). In this regard, Franklin et al. (2012) emphasize that an efficient fertilization program is required to generate high seed yields, which could allow determining the response curve in relation to the combination of $\mathrm{N}$, $P$ and $K$, for their adequate supply, in order to reduce the production costs.

The agricultural sector faces important challenges in the production of species for bioenergy purposes. In this sense, production systems that allow higher yields of raw material for use as biofuels must be sought; such is the case of hydroponic systems, where nutrients are dissolved in water to enter the plant more easily, making nutrition more efficient for plant growth, development, and yield.

Based on the above described, this study aims to determine the effect of different fertilization doses on growth, yield and oil content of five castor bean accessions grown in hydroponics.

\section{MATERIALS AND METHODS}

The study was conducted in the ejido Diego Martín (22 43' 50.6" N $101^{\circ} 42^{\prime} 33.1^{\prime \prime}$ W), municipality of Salinas, San Luis Potosí, with an approximate altitude of 2,038 m.a.s.l., a dry temperate climate, with mean annual temperature of 16 to $18{ }^{\circ} \mathrm{C}$, and mean annual precipitation of 300 to $400 \mathrm{~mm}$ (INEGI, 2009).

Five outstanding castor bean accessions were used: El Orito (EO), from the state of Zacatecas: Encarnación de Díaz (ED), from Jalisco; and Salinas (SA), Ranchería de Guadalupe (RG) and San Luis (SL), from San Luis Potosí. These were established in an open-air hydroponics system, in pots with drip irrigation applied through drip tape lines (fertigation). Sowing was done in plastic containers with a mixture of sand:tezontle:compost (1:1:1), and transplanting to the hydroponics system took place two months later. Nutrient solution was applied using four irrigation heads, each connected to a $0.25 \mathrm{HP}$ pump and a water tank, for each fertilization level used.

Eight irrigations were applied daily (from 10 to 20 minutes each) using an eight-time programmer (Steren model TEMP-08E ${ }^{\circledR}$ ). To calculate the volume of water applied, four control drippers and eight drainage trays were installed to quantify the excess. Nutrient solutions, with increasing proportions of NPK, were: no-added fertilizer (NF), and low (LL), medium (ML) and high

\begin{tabular}{|c|c|c|c|}
\hline \multirow{2}{*}{ Fertilizer } & \multicolumn{3}{|c|}{ Fertilization level (g/1000 L of water) } \\
\hline & Low (LL) & Medium (ML) & High (HL) \\
\hline Potassium nitrate & 650 & 800 & 920 \\
\hline Calcium nitrate & 550 & 750 & 820 \\
\hline Monoammonium phosphate * & 250 & 310 & 430 \\
\hline Monopotassium phosphate ** & 250 & 310 & 430 \\
\hline Magnesium sulfate & 120 & 120 & 120 \\
\hline Iron chelate & 11 & 11 & 11 \\
\hline Copper sulfate & 0.8 & 0.8 & 0.8 \\
\hline Zinc sulfate & 0.7 & 0.7 & 0.7 \\
\hline Boric acid & 1.8 & 1.8 & 1.8 \\
\hline
\end{tabular}

* Used during vegetative growth. ** Used during seed filling. 
$(H L)$ fertilization levels, supplemented with secondary nutrients and micronutrients (Table 1). In order to support seed filling, the potassium concentration in the nutrient solution was increased after 100 DDT, when fruits began to ripen.

A randomized block experimental design was used, consisting of twenty treatments (five accessions and four fertilization levels) and three replications, for a total of $n=60$ experimental units, with a spacing of $1.5 \mathrm{~m}$ between plants and rows.

Between transplanting and 142 days after transplant (DAT), plant height, number of leaves and number of panicles, were evaluated eight times. At harvest time, dry matter production, grain yield, root volume, root dry weight, weight of 100 seeds, leaf area, and oil content were quantified. The last one was quantified using a Soxhlet 1050 oil extractor, following the technique proposed by Loredo et al. (2012). Statistical analysis consisted of analysis of variance (ANOVA) and means comparison using Tukey and LSD tests.

\section{RESULTS AND DISCUSSION}

Results obtained from the effect of fertilization on the variables evaluated in five accessions of $R$. communis are presented and discussed below.

\section{Plant height}

Ricinus communis accessions showed differential behavior with regard to plant height (Table 2). The SA accession presented the greatest height $(179 \mathrm{~cm})$, which was significantly different from the others. It was observed that SA and SL presented faster growth at the beginning of the cycle. The ED accession maintained growth until the end of the evaluation, while in the rest of the accessions growth ceased between 100 and 110 days DAT. This may indicate that ED is a plant with a later vegetative development. On the other hand, SL showed a reduction in height from 121 to 142 days DAT, with a loss of leaves, which could be related to this reduction in growth.

Regarding the fertilization levels tested (Table 2), it was observed that the differences in castor bean plant height at 142 DAT were less than $14 \mathrm{~cm}$ between the levels with fertilization. In this last evaluation, the addition of fertilizer increased height by more than $100 \%$ compared to the control (NF), although the difference was not significant between the three fertilization levels. After 60 DAT, $R$. communis showed the highest height values with the ML fertilization.

In this study, plant hight ranged from 1.27 to $1.79 \mathrm{~m}$. Jiménez et al. (2015) and Salazar et al. (2014) report heights of 1.64 to $2.76 \mathrm{~m}$ for two accessions from Durango and two hybrids of castor bean. In another work, Solís et al. (2016) obtained plant heights from 0.68 to $1.11 \mathrm{~m}$, for 11 varieties of castor bean and one unimproved collected seed, which were smaller than the ones found in this study.

As an example of the plant growth during the period evaluated, Figure 1 shows the height of the EO accession, depending on the fertilization levels. It can be seen that there were no significant differences

\begin{tabular}{|c|c|c|c|c|c|c|c|c|c|}
\hline \multirow{2}{*}{ DAT } & \multicolumn{5}{|c|}{ Accession } & \multicolumn{4}{|c|}{ Fertilization level } \\
\hline & EO & ED & SA & $\mathrm{RG}$ & SL & NF & LL & $M L$ & $\mathrm{HL}$ \\
\hline 0 & 15 a & $14 \mathrm{a}$ & $27 a$ & $17 \mathrm{a}$ & $24 a$ & 13 a & $13 a$ & $14 \mathrm{a}$ & $14 a$ \\
\hline 22 & 22 b & $23 b$ & $36 a$ & $21 b$ & 34 a & $27 a$ & $26 a$ & $27 a$ & $28 a$ \\
\hline 39 & $53 c$ & $56 c$ & $75 a$ & $51 \mathrm{c}$ & 64 b & $36 \mathrm{~b}$ & $64 \mathrm{~b}$ & $68 \mathrm{ab}$ & $70 \mathrm{a}$ \\
\hline 60 & $79 c$ & $87 b$ & 108 a & $77 c$ & 90 b & $50 \mathrm{c}$ & $98 \mathrm{~b}$ & $103 a$ & $103 a$ \\
\hline 74 & $94 c$ & $110 \mathrm{~b}$ & 141 a & $97 c$ & $110 \mathrm{~b}$ & $63 \mathrm{~b}$ & $117 b$ & $133 a$ & $129 a$ \\
\hline 92 & $121 \mathrm{~b}$ & $135 \mathrm{~b}$ & 169 a & $118 b$ & $128 \mathrm{bc}$ & $76 \mathrm{~b}$ & $152 \mathrm{a}$ & $156 \mathrm{a}$ & $151 \mathrm{a}$ \\
\hline 106 & $126 \mathrm{c}$ & $143 \mathrm{~b}$ & $180 \mathrm{a}$ & $121 \mathrm{c}$ & $131 \mathrm{c}$ & $78 \mathrm{~b}$ & $164 \mathrm{a}$ & $162 \mathrm{a}$ & $157 \mathrm{a}$ \\
\hline 121 & $130 \mathrm{c}$ & $149 \mathrm{~b}$ & 179 a & $124 c$ & $149 \mathrm{~b}$ & $78 c$ & $164 a b$ & $172 \mathrm{a}$ & $159 \mathrm{~b}$ \\
\hline 142 & 133 b & $155 b$ & 179 a & $127 b$ & 135 b & $77 b$ & $168 \mathrm{a}$ & $176 \mathrm{a}$ & $163 a$ \\
\hline
\end{tabular}

Means with different letters within the same sampling time (DAT) (for either Accession or Fertlization level) are statistically different (Tukey, $\mathrm{p} \leq 0.5$ ). Accessions: $\mathrm{EO}=\mathrm{El}$ Orito, $\mathrm{ED}=$ Encarnación de Díaz, $\mathrm{SA}=$ Salinas, $\mathrm{RG}=$ Ranchería de Guadalupe, $\mathrm{SL}=$ San Luis. Fertilization levels: NF $=$ No fertilizer, $L L=$ Low level, $M L=$ Medium level, and $H L=$ High level. 


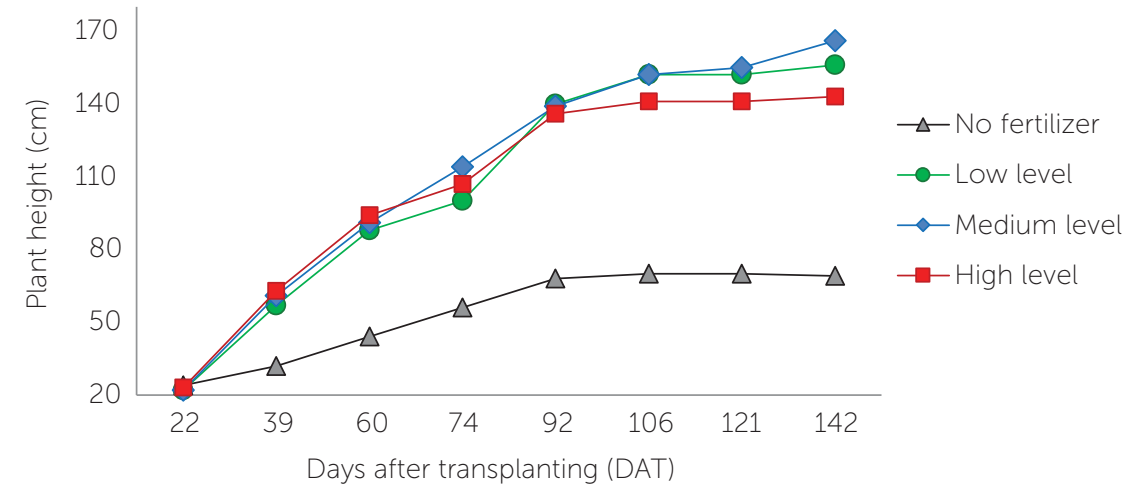

Figure 1. Plant height over time of EO accession in response to fertilization level.

between fertilization treatments, although the NM material presented the highest values, reaching $176 \mathrm{~cm}$ at 142 DAT. The NF level showed the lowest heights, registering a maximum value $(78 \mathrm{~cm})$ at 106 and 121 DAT. In all the fertilization treatments, similar height values were observed during the first 95 DAT. The same trend was present in the rest of the accessions. In this regard, Silva et al. (2003) observed significant differences in plant height at 100 DAT with the use of increasing doses of $N\left(0,30,60\right.$ and $\left.120 \mathrm{~kg} \mathrm{ha}^{-1}\right)$, with $120 \mathrm{~kg} \mathrm{ha}^{-1}$ being the best treatment.

\section{Number of leaves}

For the last evaluation (at 142 DAT), there were significant differences in the number of leaves per plant, both between the accessions and between the fertilization levels. The RG, ED and EO accessions showed the highest leaf production, with 203, 193 and 177 leaves, respectively, which were statistically different from those of SL (131) and SA (118). By fertilization level, there were only significant differences between the unfertilized level (16 leaves) and the low (226), medium (204) and high (204) levels; there were no differences among $L L, M L$, and $H L$ of fertilization.

In the control treatment (NF), the behavior of the number of leaves (no fertilizer) was very peculiar, since it reached a maximum of 29 at 60

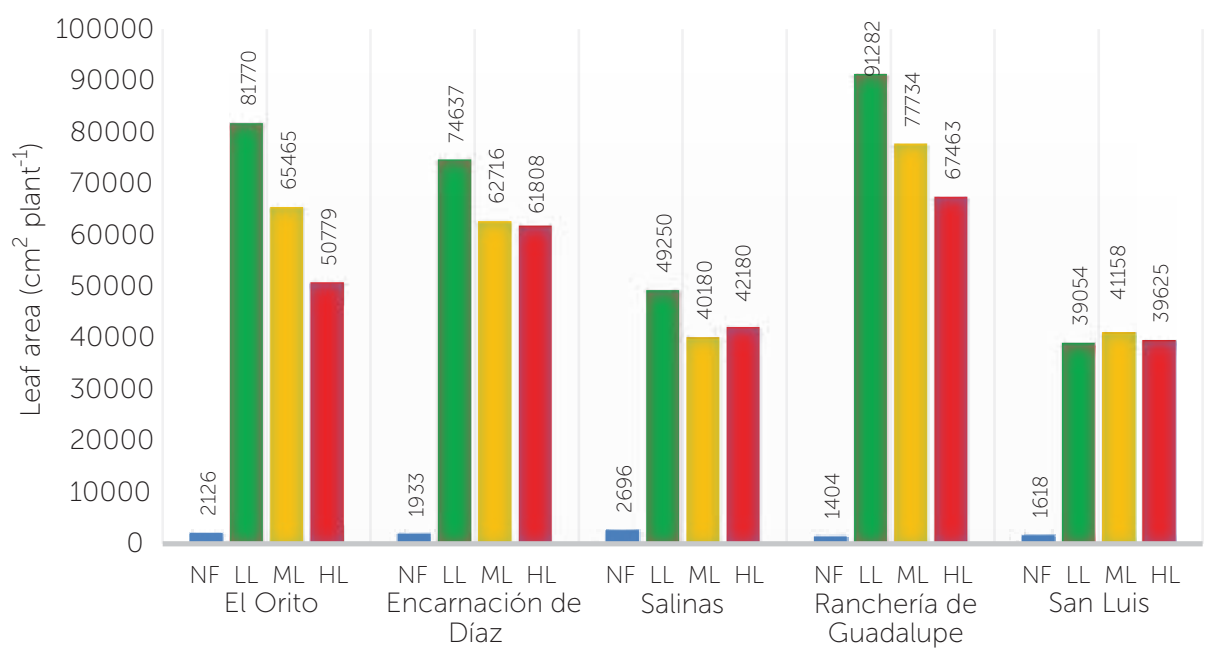

Fertilization levels: NF, No fertilizer; LL, Low level; ML, Medium level, HL, High level.

Figure 2. Leaf area accumulation in five castor bean accessions in response to fertilization levels.
DAT, and decreased to 16 on the last evaluation (142 DAT). In the treatments with fertilization, the number of leaves always increased over time, reaching its highest value in the last evaluation. This result shows that castor bean requires fertilization, as suggested by Magalhães et al. (2002), Severino et al. (2006), and Franklin et al. (2012).

\section{Leaf area}

Regarding leaf area (Figure 2), significant differences were observed between the accessions. The Tukey test formed three groups. In the first group, RG was the most productive, with an average of $59.471 \mathrm{~cm}^{2}$ plant $^{-1}$; in the second group, EO and ED showed leaf areas of 50.034 and $50.273 \mathrm{~cm}^{2}$ plant $^{-1}$, respectively. In the third group, with the lowest leaf area, SA and SLP had 33,577 and $30,364 \mathrm{~cm}^{2}$ plant $^{-1}$, respectively.

There were also statistical differences among fertilization levels, and Tukey's test formed three groups: LL was in the first group, which showed the highest production, with $67,199 \mathrm{~cm}^{2}$ plant $^{-1}$; in the second group, $\mathrm{ML}$ and $\mathrm{HL}$ accessions presents leaf areas of 57,450 and $52,371 \mathrm{~cm}^{2}$ plant $^{-1}$, respectively. The NF level only produced an average of 1,956 $\mathrm{cm}^{2}$ plant $^{-1}$.

Figure 2 shows the interaction of accessions with the fertilizer levels on leaf area production. In general, it was observed that fertilizers at ML and $\mathrm{HL}$ had a negative effect on leaf area, compared to LL. RG had the highest leaf area with $L L$ fertilization; the EO accession with LL was the second highest producer. The NF treatment showed the lowest leaf 
area, producing only 5-10\% compared to the fertilized levels ( $L L, M L$ and $H L$ ).

Fertilization levels: NF, No fertilizer; LL, Low level; ML, Medium level, HL, High level.

\section{Root volume and dry weight}

There were statistical differences in root volume and dry weight, both between accessions and between fertilization levels (Table 3). By accession, SA showed the greatest volume $\left(4,146 \mathrm{~mL}\right.$ plant $\left.^{-1}\right)$ and dry weight (405 $\mathrm{g} \mathrm{plant}^{-1}$ ), which were not different from those of ED; however both of them were different from the rest of the accessions. As for the level of fertilization, significant differences were only registered between the level without fertilization and those with fertilization for the two variables, with no differences among $L L, M L$, and $H L$. These results show that fertilizing castor bean, even at the low level, increases both root volume and root dry weight by about 3.9 and 5.7 times their values, respectively, with implications in the soil exploration area for access to moisture and nutrients.

\section{Number of panicles}

There were also significant differences in the number of panicles per plant, both between accessions and between fertilization levels. Among accessions, SL was the highest producer with 27 panicles, followed by ED with 25. The EO and RG accessions showed very similar numbers (18 and 19, respectively), while SA was the lowest producer, with 14 panicles.

Regarding fertilization levels, there were only significant differences between the level without fertilization (NF), with only 2 panicles, and those with fertilization, which presented 24, 27 and 29, with the LL, ML and HL levels, respectively.

\section{Dry matter production}

Regarding the dry matter produced (g plant ${ }^{-1}$ ), at 142 DAT the highest production was registered in ED, with 841; on the other hand, the EO, SA, and RG accessions produced around 817, with differences of two grams between them. SL produced only $549 \mathrm{~g} \mathrm{plant}^{-1}$, being statistically different from the rest. It was observed that accessions showed different physical characteristics, such as very elongated and thick stems in SA, and EO,
$E D$, and RG having more branches and leaves; even so, they had a similarity in terms of dry matter production.

There were no significant differences in dry matter production among $L L, M L$ and $H L$ fertilization levels (831.6, 831.6, 837.2 $\mathrm{g} \mathrm{plant}^{-1}$, respectively). However, when no fertilizer was applied, dry matter accumulation was only $32 \mathrm{~g} \mathrm{plant}^{-1}$. Thus, it is inferred that fertilizing castor bean, even at a low level, is required to increase dry matter production; in fact, in this study EO, ED and RG accessions produced the highest amount of dry matter with the LL treatment.

\section{Grain yield}

There were significant differences in grain yield only between the unfertilized level (31 $\mathrm{g} \mathrm{plant}^{-1}$ ) and the low, medium and high fertilization levels (1103, 973 and $967 \mathrm{~g}$ plant $^{-1}$, respectively), although between the latter three the differences were not significant. In addition, there were no significant differences in seed yield among accessions. ED was the most productive (681 $\mathrm{g} \mathrm{plant}^{-1}$ ), followed by RG, EO, SA and SL (661, 652, 539 and 530 9 plant $^{-1}$, respectively). It was observed that SL was damaged by a severe wind event; some branches were broken, showing a weakness in their basal part, which is accentuated when green, hydrated and heavier panicles are present. This could have influenced yield, due to a possible loss of fruits.

Regarding grain yield per accession as a function of the fertilization level, Figure 3 shows a differentiated response of the accessions to fertilizer application, since some of them, such as EO and SA, reached the maximum yield 
with $\mathrm{HL}$ fertilization, while ED, RG and $S L$ produced more grain with $L L$ fertilization. This indicates that in some cases grain yield was affected as more fertilizer was applied; however, it is very evident that castor bean responds to fertilization, since even with the $L L$ treatment grain yield increased more than 11 times, compared to the NF control level. This confirms what Severino et al. (2006) mentioned in relation to the fact that castor bean requires fertile soils in order to ensure high yields.

The results obtained in this study are similar to those obtained by Solis et al. (2016) with a seed collected in Estado de México and 10 varieties from Chiapas and Michoacán evaluated in soil, and reporting yields ranging from 0.3 to $1.1 \mathrm{~kg} \mathrm{plant}^{-1}$.

\section{Seed oil concentration}

The highest oil concentration in castor bean seeds was observed in the ED accession (37\%), followed by SA and SL (both with $34 \%)$ and RG (33\%), while EO had the lowest concentration (32\%). With reference to fertilization, the NF and LL levels led to a 32\% oil production, while the highest production was obtained with $\mathrm{ML}$ (38\%), and the lowest with $\mathrm{HL}(31 \%)$. Figure 4 shows the percentage of oil by accession as a function of the fertilization level. The highest concentration was obtained with the SA accession fertilized at ML, followed by the ED accession with the $M L$ and $H L$ levels of fertilization. Something that stands out is that in the SL and EO accessions the highest concentration of oil in the seed was obtained without fertilization.

According to the data, the average castor oil yield with the NF level was

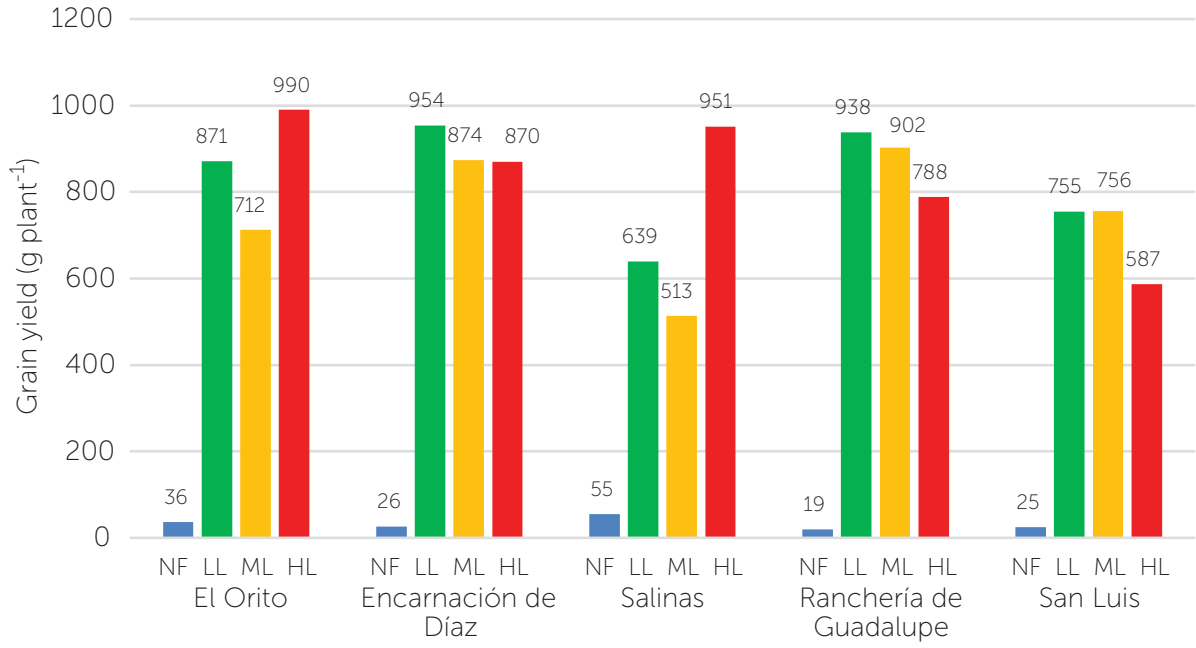

Fertilization levels: NF, No fertilizer; LL, Low level; ML, Medium level; HL, High level

Figure 3. Seed yield of five castor bean accessions in response to fertilization level

$44 \mathrm{~kg} \mathrm{ha}^{-1}$, while with the $\mathrm{LL}, \mathrm{ML}$ and $\mathrm{HL}$ levels, production values were $1,568,1,643$ and $919 \mathrm{~kg} \mathrm{ha}^{-1}$, respectively.

Oil concentration values in this study (28 to 52\%) were higher than those reported by Salazar et al. (2014) and Jiménez et al. (2015), which ranged from 13.6 to $40.3 \%$ for seeds from Durango and some hybrids. Our values are within those reported by Goytia-Jiménez et al. (2011) for 151 materials from Chiapas, with oil concentrations ranging from 12.2 to $64.8 \%$. In turn, Martínez et al. (2012) reported higher values (between 51.9 to 63.3\%) for 10 castor bean varieties.

\section{Weight of 100 seeds}

The weights of 100 seeds of castor bean accessions evaluated are shown in Table 4. According to the data, three groups were formed (small, medium and large): small seeds were found in EO and RG (with a 100-seed weight of 9.8 and $13.2 \mathrm{~g}$ ); the ED accession had medium-size seeds (between 30.2 and $32.5 \mathrm{~g}$ ); and large seeds were harvested in SA and SL (between 31.7 and

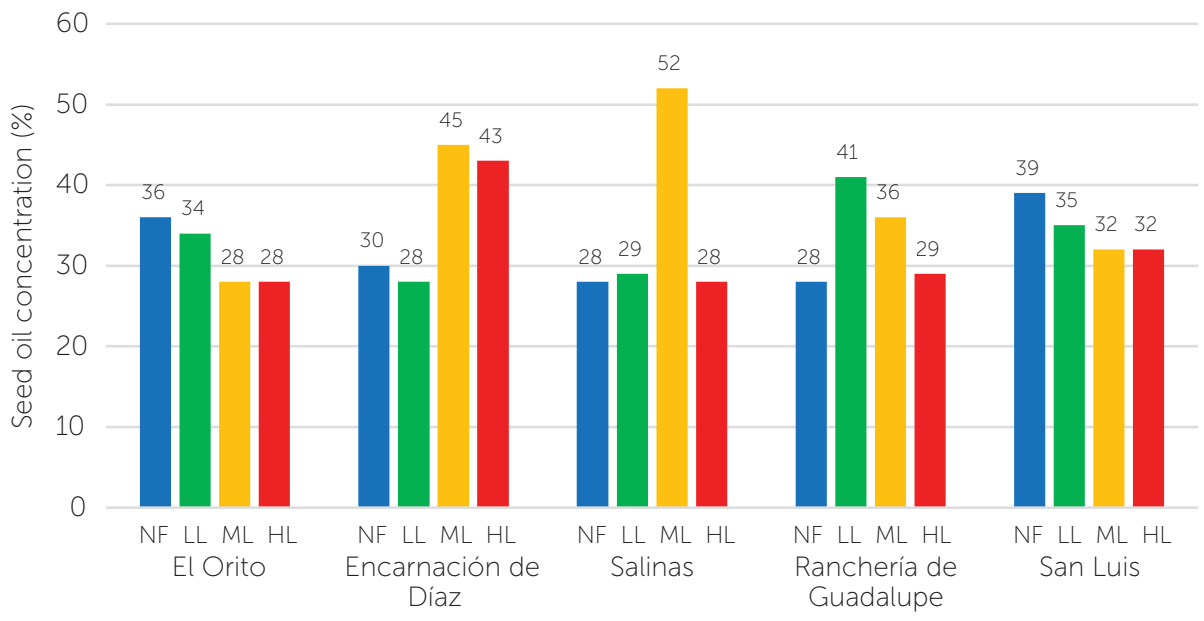

Fertilization levels: NF, No fertilizer; LL, Low level; ML, Medium level; HL, High level. 


\begin{tabular}{|c|c|c|c|c|c|}
\hline \multirow[b]{2}{*}{ Fertilization level } & \multicolumn{5}{|c|}{ Accessions } \\
\hline & EL Orito (EO) & $\begin{array}{c}\text { Encarnación de Díaz } \\
\text { (ED) }\end{array}$ & Salinas (SL) & $\begin{array}{l}\text { Ranchería de } \\
\text { Guadalupe (RG) }\end{array}$ & San Luis (SL) \\
\hline No Fertilizer (NF) & 10.6 & 30.2 & 40.3 & 9.8 & 31.7 \\
\hline Low level (LL) & 13.2 & 32.0 & 60.5 & 12.0 & 46.3 \\
\hline Medium level (ML) & 12.4 & 31.3 & 57.3 & 11.0 & 52.8 \\
\hline High level (HL) & 11.7 & 32.5 & 53.5 & 12.0 & 52.5 \\
\hline
\end{tabular}

$60.5 \mathrm{~g})$. Seeds from the SL accession showed more variation among the fertilization levels. Vasco (2014) evaluated the weight of 100 seeds and mentions that EO collection had an average weight of $11 \mathrm{~g}$, ED $21.6 \mathrm{~g}$, SL 52.9, and RG had a weight of 10.1; these values are somehow similar to the ones in this study.

\section{CONCLUSIONS}

Castor bean showed a significant response to fertilization, since even with the low level, it increased more than 11 times the grain yield compared to the control treatment. There were no differences among the fertilization levels (low, medium and high). The responses to fertilization were differentiated among accessions, with EO and SA showing the highest yield with $H \mathrm{~L}$, while $E D$ and $R G$ had the highest yield with LL. Seed yield per accession ranged from 530 to $681 \mathrm{~g} \mathrm{plant}^{-1}$, with no significant differences. The EO accession had the highest yield (990 $\mathrm{g} \mathrm{plant}^{-1}$ ), achieved with the LL of fertilization. ED (45\%) and SA (52\%) accessions were the highest oil producers, when grown with the LL fertilization. The accessions evaluated showed homogeneous plant heights, ranging from 140 to $180 \mathrm{~cm}$. The RG accession had the highest number of leaves (203) and the largest leaf area $\left(91,282 \mathrm{~cm}^{2}\right.$ plant $\left.^{-1}\right)$. SA produced 15 to $25 \%$ more roots than the other accessions.

The information reported here serves as a basis for accession management and for considering some traits for genetic breeding.

\section{REFERENCES}

Babita, M., Maheswari, M., Rao, L.M, Shanker, A.K., \& Rao, D.G. (2010). Osmotic adjustment, drought tolerance and yield in castor (Ricinus communis L.) hybrids. Environ. Exp. Bot., 69, 243-249.

Beltrão, N.E.M., Silva, L.C., Vasconcelos, O.L., Azevedo, D.M., Vieira, D.J. (2001). Fitologia. En Pedrosa, D.M, \& Lima, E. (Eds.). O agronegócio da mamona no Brasil (pp. 37-61). Campina Grande, Brasil: Embrapa

Cardona, C.A., Orrego, C.E., Gutiérrez, L.F. (2009). La higuerilla: una alternativa agroindustrial. Manizales, Colombia: Artes Gráficas Tizán.
Caupin, H.J. (1997). Products from castor oil: past, present, and future. En F.D. Gunstone, \& F.B. Padley (Eds.), Lipid Technologies and Applications (pp. 787-795). New York, USA: Marcel Dekker.

Comar, V., Tilley, D., Felix, E., Turdera, M., \& Neto, M.C. (june of 2004). Comparative emergy evaluation of castor bean (Ricinus communis) production systems in Brazil and the US. En Ortega, E., \& Ulgiati, S. (Editors), Advances in Energy Studies. IV Biennial International Workshop, Unicamp, Campinas, SP, Brazil.

Franklin, D.M.E., Garófalo, C.L.H., Carvallo, G.H.O., \& Dantas, D.L.R. (2012). Crescimento e produção de duas cultivares de mamoneira sob fertilização NPK. Revista Caatinga, Mossoró 25(2), 35-43

Goytia, J.M.A., Gallegos, G.R., Gallegos, C.R., Barrales, D.S., Zarate, B.R., Macías, C.U.A., Jiménez, R.E., Benigno, C.P., Vázquez, R.J., García, G.O., Méndez, F.E.I., \& Nolasco, J.U. (2015). Paquete tecnológico para la producción de higuerilla (Ricinus communis L.) en Valles Centrales de Oaxaca. Chapingo, Texcoco, Edo. de México: Universidad Autónoma Chapingo.

INEGI. (2009). Prontuario de información geográfica municipal de los Estados Unidos Mexicanos. Salinas, San Luis Potosí. Recuperado de https://www.inegi.org.mx/contenidos/app/ mexicocifras/datos_geograficos/24/24025.pdf

Jiménez, O.R., Rosales, S.R., Galindo, V.C.F., Jiménez, R.R., y Domínguez, M.P.A. (2015). Rendimiento de variedades e híbridos de higuerilla cultivados en diferentes ambientes de Durango, México. Agrofaz 15(1), 135-146.

Jiménez, O.R., Rosales, S.R., y Domínguez, M.P.A. (Coordinadores). 2016. Estrategias para el uso integral de la higuerilla en México. Durango, Dgo., México. SAGARPA-INIFAP-CIRNOC.

Loredo-Dávila, S., Espinosa-Hernández, V., Goytia-Jiménez, M.A., DiazBallote, L., Soto-Hernández, R.M., \& Marrone, P.G. (2012). Fatty acid methyl ester profile from lupinus in the identification of sweet and bitter species from this gender with oil of Lupinus uncinatus Schlecht seeds. Journal of Nutrition \& Food Sciences 2:158. doi: 10.4172/2155-9600.1000158

Magalhães, R.T., Oliveira, I.P., Kliemann, H.J. (2002). Relações da produção de massa seca e as quantidades de nutrientes exportados por Brachiaria brizantha em solos sob o manejo pelo sistema "barreirão". Pesquisa Agropecuária Tropical, 32, 13-20. doi: 10.5216/pat.v32i1.2435

Martínez, V.B.B., Hernández, C.M., Solís, B.J.L., y Zamarripa, C.A. (julio de 2012). Calidad agroindustrial del aceite de higuerilla (Ricinus communis L.) para la producción de bioenergéticos en México. En Miranda, R.M.A. (Presidente), Desafios e oportunidades. V Congresso Brasileiro de Mamona / II Simpósio Internacional de Oleaginosas Energéticas \& I Fórum Capixaba de Piñhao Manso, Campina Grande, Brasil. 
Méndez-Gallegos, S.J., Rössel, D., Amante-Orozco, A., Gómez-González, A., y García-Herrera, J. (2010). El nopal en la producción de biocombustibles. Revista Salud Pública y Nutrición, Edición especial No. 5-2010, 70-84.

Ogunniyi, D.S. (2006). Castor oil: A vital industrial raw material. Bioresource Technology 97(9), 1086-1091.

SAGARPA. (2017). Bioenergéticos mexicanos: Higuerilla, Jatropha curcas, Sorgo dulce. Planeación Agrícola Nacional 2017-2030. Recuperado de https://www.gob.mx/cms/ uploads/attachment/file/257070/Potencial-Bioenerg_ticos.pdf

Salazar, S.L.M., Rosales, S.R., Jiménez, O.R., Ríos, S.J.C., y Breton, V.B.A. (2014). Rendimiento de la higuerilla (Ricinus communis L.) cultivada en dos densidades de población en Durango, México. Agrofaz 14(1), 129-135.

Severino, M.I.L., Silva, V.A., Farias, N.E., Beltrão, M., \& Cardoso, G.D. (2006). Sexual expression of castor influenced by fertilizer and mepiquat chloride. Rev. Ciên. Agron, 37, 339-344.

Silva, J.V., Lacerda, C.F., Costa, P.H.A., Enéas, F.J., Gomes, F.E., \& Prisco, J.T. (2003). Physiological responses of $\mathrm{NaCl}$ stressed cowpea plants grown in nutrient solution supplemented with $\mathrm{CaCl}_{2}$. Brazilian Journal of Plant Physiology, 15(2), 99-105. https://dx.doi.org/10.1590/ S1677-04202003000200005

Solís, B.J.L., Muñoz, O.A., Escalante, E.J.A.S., y Zamarripa, C.A. (2016). Crecimiento de variedades y componentes del rendimiento de higuerilla (Ricinus communis L.) en Montecillo, Estado de México. Revista Mexicana de Ciencias Agrícolas, 7(2), 311-323.

Vasco, L.J.F. (2014). Análisis químico proximal y parámetros físicos de semillas de higuerilla (Ricinus communis L.) (tesina de maestría tecnológica). Colegio de Postgraduados Campus SLP. Salinas de Hgo., SLP, México.

Velasco, L., Rojas-Barros, P., \& Fernández-Martínez, J.M. (2005). Fatty acid and tocopherol accumulation in the seeds of a high oleic acid castor mutant. Ind. Crops Prod., 22, 201-206

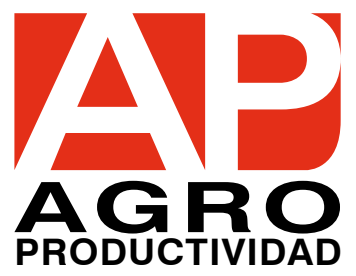

44 | 4 EV AOGRO 